\title{
Short-term vegetation responses to the first prescribed burn in an urban pine rockland preserve
}

\author{
Brittany Harris $^{{ }^{*}}$ (D) Ariel Freidenreich ${ }^{2}$ D, Eric Betancourt ${ }^{2}$ and Krishnaswarmy Jayachandran ${ }^{3}$ (D)
}

\begin{abstract}
Background: Preserving fire-dependent ecosystems can mitigate biodiversity loss from urbanization, but prescribing fire is challenging near human habitation. Consequently, dereliction of fire-dependent forests is widespread in urban fragments. Natural disturbance-based management, like prescribing fire, is gaining global acceptance, yet it is unclear what affects prolonged exclusion have on the initial regeneration of isolated plant communities immediately after fire is reintroduced. We took advantage of the first prescribed low-intensity burn on a university pine rockland nature preserve in South Florida, USA, to gain insight. We measured the changes in plant community composition and vegetation cover 1 week before the prescribed burn, and again 1,2, and 14 weeks after to assess the early and short-term stages of recovery.

Results: The fire consumed substantial leaf litter, surface fuels, and canopy leaves, increasing sunlight availability to the understory and exposing bare ground. Many woody plants perished within a week post-burn, particularly invasive shrubs; however, germinating and resprouting plant growth were rapid. By 14 weeks, vegetation covered more of the ground than before the burn, although the upper canopy remained relatively open. Rarefied species richness was recovered by 14 weeks but did not exceed pre-burn levels. Invasive species richness was also maintained post-burn. Despite no overall changes in the community structure, our correspondence analysis and analysis of similarity of the plant community suggest high species turnover from the pre-burn to the final community surveyed, with an intermediate turnover in between.

Conclusion: The endangered pine rockland ecosystem, like many fire-dependent ecosystems, is threatened by habitat loss and fire suppression. Managing urban preserves with periodic burns is essential for supporting habitat for endemic species while decreasing demands for manual and time-intensive maintenance. Our study demonstrates that seedling recruitment from early plantings of native species can contribute significantly and immediately to restoration efforts in a fire-excluded urban preserve; however, many changes were ephemeral. Supplemental burns are likely necessary to further reduce vegetation density and sustain changes to the community composition.
\end{abstract}

Keywords: Fire-dependent ecosystems, Fire suppression, Urban restoration, Urban nature preserves, Post-fire seedling recruitment

\footnotetext{
* Correspondence: bharr063@fiu.edu

${ }^{1}$ Institute of Environment, Department of Biological Sciences, CASE 151,

Florida International University, 11200 SW 8th St., Miami, FL 33199, USA

Full list of author information is available at the end of the article
}

\section{Springer Open}

(c) The Author(s). 2021 Open Access This article is licensed under a Creative Commons Attribution 4.0 International License, which permits use, sharing, adaptation, distribution and reproduction in any medium or format, as long as you give appropriate credit to the original author(s) and the source, provide a link to the Creative Commons licence, and indicate if changes were made. The images or other third party material in this article are included in the article's Creative Commons licence, unless indicated otherwise in a credit line to the material. If material is not included in the article's Creative Commons licence and your intended use is not permitted by statutory regulation or exceeds the permitted use, you will need to obtain permission directly from the copyright holder. To view a copy of this licence, visit http://creativecommons.org/licenses/by/4.0/. 


\section{Resumen}

Antecedentes: El preservar los ecosistemas dependientes del fuego puede mitigar la pérdida de biodiversidad por urbanización, aunque la prescripción de quemas cercanas a urbanizaciones implica un desafío. Consecuentemente, el abandono de bosques dependientes del fuego es generalizado en urbanizaciones fragmentadas. El manejo basado en disturbios naturales, como las quemas prescriptas, está ganando aceptación global, aunque no está claro todavía como afecta la exclusión prolongada del fuego en la regeneración inicial de comunidades aisladas inmediatamente luego de reintroducido el fuego. Aprovechamos la primera quema prescripta de baja intensidad en una reserva natural de pinos de Florida (pine rockland) en el sur de la Florida, EEUU, para ganar experiencia en el tema. Medimos los cambios en la composición de la comunidad y la cobertura de la vegetación una semana antes de la quema prescripta, y nuevamente 1, 2 y 14 semanas después, para determinar los efectos tempranos y de corto plazo de la recuperación.

Resultados: El fuego consumió una cantidad sustancial de acículas, de combustibles superficiales y de hojas de dosel, incrementando la cantidad de luz solar en el sotobosque y en el suelo desnudo expuesto. Muchas plantas leñosas perecieron dentro de una semana post-fuego, particularmente arbustos invasores; sin embargo la germinación y el rebrote de plantas fue rápido. A las catorce semanas, la vegetación cubrió más superficie del suelo que lo que había antes de la quema, aunque el dosel superior permaneció relativamente abierto. La laxa riqueza de especies se recuperó a las catorce semanas, pero no excedió los niveles previos a la quema. La riqueza de especies invasoras también se mantuvo en la post-quema. A pesar de que no hubo cambios generalizados en la estructura de la comunidad, nuestro análisis de correspondencia y el análisis de similaridad de la comunidad de plantas sugiere una alta rotación de especies desde la pre-quema hasta las etapas finales del relevamiento previas a la quema, con una rotación intermedia entre medio de ambas.

Conclusiones: El ecosistema en peligro de extinción denominado "pine rockland", como cualquier otro ecosistema dependiente del fuego, es amenazado por la pérdida de hábitat y la supresión de incendios. El manejo de reservas urbanas con quemas periódicas es esencial para sostener el hábitat de especies endémicas y decrecer las demandas para su mantenimiento de forma manual y tiempo-intensiva. Nuestro estudio demuestra que el reclutamiento de plántulas provenientes de plantaciones de nativas puede contribuir significativa e inmediatamente a los esfuerzos de restauración en una reserva urbana en la cual el fuego ha sido excluido; desde luego, algunos de esto cambios fueron efímeros. Quemas suplementarias son probablemente necesarias para reducir la densidad de la vegetación y mantener los cambios en la composición de la comunidad.

\section{Background}

Restoring nature preserves in urban areas is a promising avenue for conservation in the modern era (Dunn et al. 2006). If managed with ecological processes as a guiding principle, urban preserves can create stepping stones and corridors for species and ecosystem functions to persist. Further, they connect residents to nature and provide an experiential educational tool for science and conservation awareness (Elmqvist et al. 2015).

An ongoing challenge in urban land management is maintaining ecosystem functioning with minimal human interference (Lundholm 2015). Conversely, the task of managing fire-dependent forests is laden with complexities (van Wilgen et al. 2012). Negative public perception and safety concerns further impede fire management (Ryan et al. 2013). As such, fire is commonly excluded in the urban landscape (Koptur 2006), despite the increasing need to conserve fire-dependent forest fragments (Jones and Koptur 2017). Instead, suppressing fire results in losses of plant functional groups (Folke et al. 2004; Johnstone et al. 2016), such as the replacement of fire- adapted plants by fire-intolerant hardwoods. Turnover of the plant community is often accompanied by changes in the fuel structure and increased vegetation density (Mitchell et al. 2009). Furthermore, long-term fire suppression can result in alternative stable states that are likely not reversible. For example, firedependent pine rockland ecosystems in South Florida, USA, can transition into late successional hardwood hammocks in as little as 20 to 30 years without fire (Ross et al. 2009). In urban pine rockland preserves, this transition by native hardwoods is often accompanied by encroaching invasive species (Possley et al. 2014).

Urban fire restoration is a relevant and growing field of study. Less than $2 \%$ of pine rockland remains intact in South Florida, and nearly 20\% remaining occurs in small urban fragments (USFWS 1999). Expanding the footprint of this globally endangered ecosystem is gaining interest in the conservation community, but restoration outcomes of introduced fire are not well studied in constructed preserves. Furthermore, evidence of initial vegetation responses to prescribed burning following 
prolonged exclusion is scarce (Kobziar et al. 2015). Short-term restoration assessments generally include surveys few to many months post-burn (Abrahamson and Abrahamson 1996; Abrahamson et al. 2021). Although delayed surveys are informative for long-term restoration goals, immediate responses such as seedling recruitment and surface litter removal may remain undetected with increasing time between surveys. For example, fast-growing native and invasive species may respond rapidly to increased nutrients and sunlight when fire has long been excluded (Abrahamson and Abrahamson 1996). Under such circumstances, seedlings may be outcompeted, yet these seed bank contributions are significant for restoration potential (Cohen 2004).

We investigated the initial plant community responses to prescribed fire in a university pine rockland preserve with no previous known fire history. Namely, we were interested in immediate responses and those occurring within less than 4 months. Our specific goal was to understand how vegetation structure and plant community composition initially respond to fire, including seedling recruitment and resprouting of native and invasive species.

\section{Methods}

\section{Site description}

The prescribed burn was conducted at Florida International University's Nature Preserve $\left(25.7548^{\circ} \mathrm{N}\right.$, $\left.80.3794^{\circ} \mathrm{W}\right)$ in Miami, FL. The 0.4-ha pine rockland (Pineland) is centered within a 3.7-ha preserve, designed in 1978. Cleared trails surround the Pineland, separating it from a wetland ecosystem and hardwood hammocka South Florida late successional forest. The initial and subsequent plantings include species known to occur in pine rockland, and a subset of this accumulated planting list was present in our pre-burn survey. Besides supplemental plantings and occasional removals of invasive plants, the preserve was managed only by hand for the 40 years before our first prescribed burn. Consequently, hardwood trees and invasive shrubs and grasses were abundant.

Pine rockland is maintained by a fire frequency of 310 years (Snyder et al. 1990). Forests managed with frequent fire regimes are sparsely dominated by a Florida slash pine (Pinus elliottii Engelm) canopy with few midcanopy palms and shrubs (Snyder et al. 2005), like saw palmetto (Serenoa repens (W. Bartram) Small) and Jamaican nettle tree (Trema micrantha (L.) Blume). The herbaceous understory is species rich and includes several endemic and rare plants, such as Small's milkpea (Galactia smallii H.J. Rogers ex Herndon; Gann et al. 2020; O'Brien 1998). Soils are shallow, and the oolitic limestone is often visible between herbaceous plants. The prolonged absence of fire alters species composition as well as vegetation and fuel structure. Specifically, herbaceous plant diversity wanes, vegetation becomes shrubbier, and heavier fuel loads accumulate with time since burn (O’Brien 1998).

\section{Prescribed burn}

The prescribed burn was conducted by the Florida Department of Agriculture and Consumer Services Division of Forestry on 15 March 2016. The approximate temperature before fire initiation was $82^{\circ} \mathrm{F}$ with $7 \mathrm{mph}$ average wind speeds and $60 \%$ relative humidity. The whole Pineland within the preserve was burned. Backing fires, strip heading fires, heading fires, flanking fires, and dot fires were the burn techniques prescribed. The maximum acceptable crown scorch was between 10 and $40 \%$. Although the fire consumed much leaf litter, patches of unburned litter were present throughout the site, indicating a low-intensity fire.

\section{Field design}

At each survey, we established ten $1-\mathrm{m}^{2}$ quadrats from randomly selected points inside the Pineland, excluding a 5-m buffer from the perimeter. We measured canopy closure, ground cover composition, and plant composition within the quadrats for four survey periods: days before the burn (T0), 1 week (T1), 4 weeks (T4), and 14 weeks (T14) after the burn. Our surveys occurred from March to early June before the onset of the peak rainy season. Weekly average temperatures and rainfall were $76^{\circ} \mathrm{F}$ and $0 \mathrm{~cm}$ at $\mathrm{T} 0$ and $82^{\circ} \mathrm{F}$ and $1.17 \mathrm{~cm}$ at T14.

We measured the changes in environmental variables that are responsive to fire and important for firedependent understory plant communities, including light availability and leaf litter, bare soil, and vegetation cover. To measure light availability, we used a spherical densitometer at $1 \mathrm{~m}$ above each plot, and we averaged the proportion of the sky hemisphere obscured by canopy vegetation from four cardinal directions (Jennings 1999). We then estimated ground cover composition as the proportion of quadrats (1-100\%) covered by leaf litter, by shrubby and woody vegetation, by exposed soils or bare limestone, and by herbaceous vegetation. To analyze the changes in plant community structure and composition, we approximated species abundances as the sum of their presences or absences (incidences; Colwell et al. 2004) within all quadrats $(n=$ $10)$ at each survey $(n=4)$. Incidences are a proxy for abundances when individuals are difficult to ascertain, such as in resprouting and vegetatively clonal individuals (Colwell et al. 2004).

\section{Analyses}

All analyses were performed in $\mathrm{R}$ (ver. 3.4.0). We analyzed the changes in the proportions of canopy closure 
before and post-recovery using a beta-regression (Cribari-Neto and Zeileis 2010) with weeks since burn as the categorical response variable. To test for compositional changes in ground cover, we ran a compositional analysis of variance (van den Boogaart and TolosanaDelgado 2013). We first reclassified the vegetation cover for each sample as the summed proportions of herbaceous and shrubby plant cover; proportions of bare ground and leaf litter were maintained. Where ground cover classes were observed to be less than $1 \%$, we imputed the rounded zeroes using a robust linear model method (Templ et al. 2011) before taking the isometric $\log$ ratios between the cover types.

We rarefied species richness for each survey, extrapolated it to double the sample size (Hsieh et al. 2016), and calculated the confidence intervals for comparison of species richness at different stages of recovery (Colwell et al. 2004; Chao et al. 2014). We tested if the native status (native or invasive) composition was different between surveys by performing a chi-squared test of differences on counts of invasive and native species present at each survey. We then tested the probability that frequencies of plants present at each survey came from the same distributional species pool. We calculated a Jaccard binary distance matrix (Oksanen 2001) from species incidences across quadrats at each survey $(n=$ 40 ), and we performed an analysis of similarity (ANOSIM) on the distance matrix with weeks since prescribed burn as a categorical explanatory variable (permutations = 9999). To visualize these compositional changes, we performed a correspondence analysis (CA; Legendre and Legendre 2012) of species incidences before the prescribed burn and post-recovery. We displayed the first two axes of the CA, preserving the $X^{2}$ distance among survey periods (Fig. 3; Additional file 1: Table S1).

\section{Results}

Much of the upper canopy leaves and branches burned in the fire, reducing closure from $75 \%( \pm 0.03)$ to $36 \%( \pm$ 0.02 ). New leaves filled in slightly to $46 \%$ closure $( \pm$ 0.03 ) by T14, but the overall available sunlight to the understory increased $\left(\Phi=29.4, F_{3,36}=13.5, P<0.001\right)$ after burning. Similarly, fire consumed leaf litter on the ground and increased bare soil, but vegetation filled in all available soil space by T14 (Fig. 1). Woody plant cover was initially reduced post-burn but recovered to higher levels by T14. These changes to proportional ground cover compositions of vegetation, bare soil, and leaf litter were significantly different across survey periods (Pillai's trace 1.16, $F_{3,36}=16.7, P<0.001$ ). However, T1 and T4 shared similar canopy cover and ground compositional measurements.

There was a significant effect of time since burn on observed species incidences $\left(F_{3,192}=9.9, P<0.001\right)$. Of the 49 unique species identified across all surveys, 37 were native species and 12 were invasive. From this species pool, 27 were present before the prescribed burn (T0), compared to 38 species after 14 weeks (T14). Additionally, five species were observed within 4 weeks postburn that were not detected before the burn or 14 weeks after burning. Despite losses and gains of species over time, confidence intervals of T0 and T14 completely overlapped after extrapolating species accumulation curves to asymptotic coverage (Fig. 2). Similarly, invasive species richness did not significantly change across surveys $\left(X_{3}^{2}=3.19, P>0.05\right)$. While ten invasive species occurred before the burn, seven were detected in T14.

Despite the similarity in extrapolated species richness, ANOSIM results indicate that plant composition was more different across surveys than within surveys (permutations $=9999$, Global $R=0.22, P<0.001)$. For instance, 23 species occurring in the three surveys after the burn were not present in pre-burn surveys, including two invasive shrub species, one native shrub, and 20 native herbs (S1). We see $79 \%$ of this variability in species incidences separated along the first two axes of the CA (total inertia $=0.82$; Fig. 3). Survey period scores from the CA for T1 and T2 separated from T14 along the first axis (0.34 Eigenvalues) and from T0 on the second axis (0.30 Eigenvalues). Further, the composition of our final survey (T14) partitioned from the pre-burn composition (T0) on both CA axes (Fig. 3).

\section{Discussion}

The objective of the prescribed burn on the university campus preserve was to restore the plant composition of the Pineland, reminiscent of a natural pine rockland ecosystem. Specific goals were to encourage the establishment of native herbaceous plants (Barrios et al. 2011; O'Brien 1998) by reducing biomass of fire-sensitive hardwoods (Mitchell et al. 2009), decreasing canopy light interception (Cannon et al. 2017), consuming leaf litter (Ormeño et al. 2009), and providing germination opportunities from the seed bank (Liu et al. 2005). Our shortterm pre- and post-burn assessment permitted early observations of competition and rapid replacement between seedling recruitment and surviving plants. These immediate responses can inform both natural restoration potential and sources contributing to less successful restoration outcomes on a longer time frame.

Despite no former fire management in the Pineland, the low-intensity prescribed burn was effective at removing some canopy and surface fuels with little damage to fire-resistant species. Nonetheless, structural vegetation changes appeared to be short-lived, such as described in similar fire-suppressed pine forests (Abrahamson and Abrahamson 1996). For example, leaf litter was consumed but soon replenished with charred leaves and 
Before burn (T0)

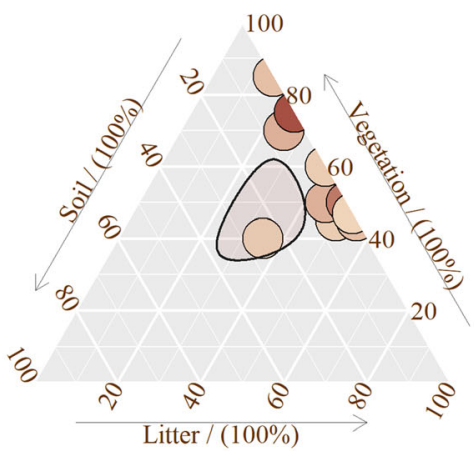

4 weeks post-burn (T4)

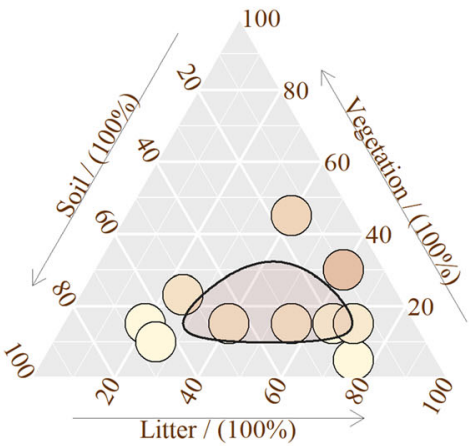

1 week post-burn $(\mathrm{T} 1)$

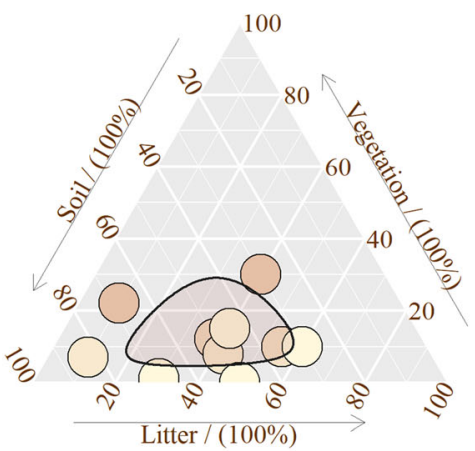

14 weeks post-burn (T14)

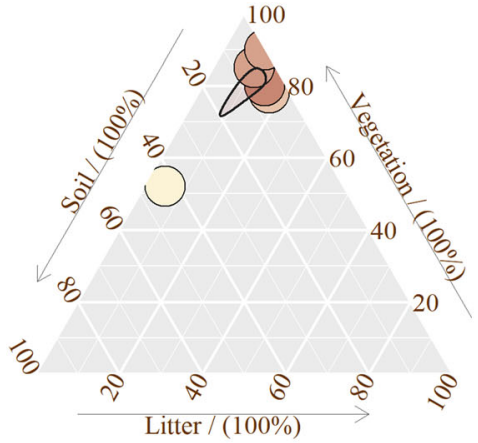

Shrub cover

$0 \% 25 \% 50 \% 75 \%$

Fig. 1 Compositions of ground cover in a managed pine rockland preserve in South Florida measured prior to the first prescribed burn (T0), 1 week post-burn (T1), 4 weeks (T4), and 14 weeks later (T14). The position of points in each ternary diagram illustrates the percent of ground surface within a quadrat covered by bare ground (soil), dead plant material (litter), and live plants (vegetation). Color depth of points separately indicates the percent of vegetation cover consisting of shrubs or trees. Ellipses within diagrams are produced from means and variances of compositions within quadrats

branches from the canopy. Additionally, exposed soil cover increased immediately post-burn but was replaced by a high density of germinating and resprouting plants within 14 weeks, including many shrub seedlings.

Plant compositional changes were also variable over a short time frame. Mortality was high for some species after the burn, but several new species germinated. Perennial fast-growing herbs like the invasive lantana (Lantana strigocamara R.W. Sanders) replaced large shrubs like lancewood (Damburneya coriacea (Sw.) Trofimov \& Rohwer) from the pre-burn community. However, juveniles of shrubs, like Jamaican nettle tree and spine fiddlewood (Citharexlyum spinosum L.), that were not abundant before the burn were frequent in the last survey. The earliest post-burn surveys also revealed important seed bank contributions. For instance, short-lived herbs, like goldenrods (Solidago L. spp.) and groundcherries (Physalis walteri Nutt.), germinated and reproduced within weeks post-burn.

We had few expectations for managing invasive species with fire, since no consensus exists on using fire to reduce invasive plants (Alba et al. 2015), largely due to species-specific differences. Indeed, invasive species richness was unchanged, but species did vary in their responses. Some invasive plants became more common (e.g., lantana and coatbuttons (Tridax procumbens L.)), others were not affected (e.g., Chinese ladder brake (Pteris vittata L.)), and some became less common, particularly invasive woody plants like shoebutton (Ardisia elliptica Thunb.) and Brazilian pepper (Schinus terebinthifolius Raddi). Invasive shrubs like Brazilian pepper can alter fire behavior and reduce the effectiveness of prescribed burning for restoration. However, when the invasive shrub's abundance is low, fires can cause high 


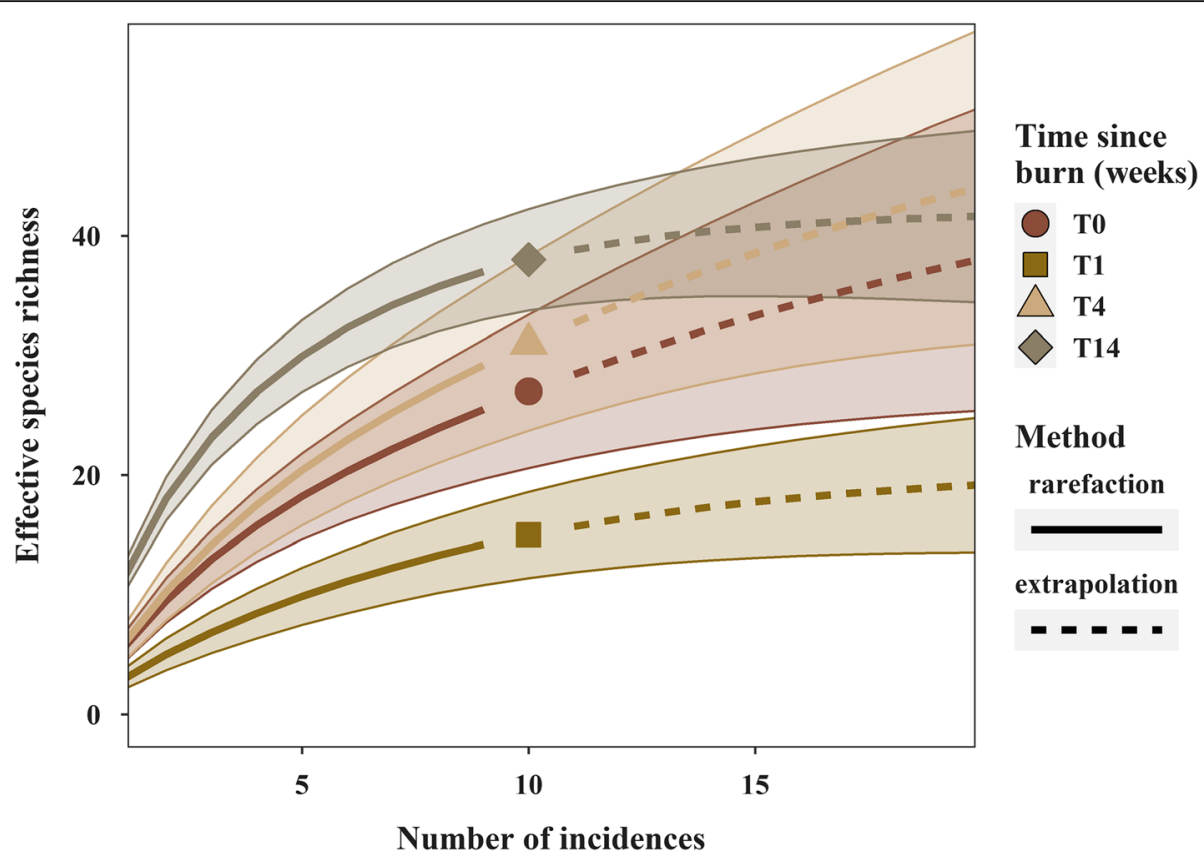

Fig. 2 Estimated species accumulation curve before and at multiple periods after a prescribed fire in a managed pine rockland on the University Campus Nature Preserve in South Florida, USA. Solid lines are plant species richness interpolated by species incidences in each sample quadrat, points indicate observed richness, and dashes are extrapolated species richness to complete sample coverage. Quadrats were surveyed 1 week before the prescribed burn (T0; circle; $n=10), 1$ week post-burn (T1; triangle), 4 weeks after (T4; square), and at 14 weeks (T14; rhombus). Confidence intervals of interpolated and extrapolated species richness are shaded with corresponding colors of sample times as indicated in the legend

mortality and be an effective restoration tool (Stevens and Beckage 2009). Low pre-burn abundances of Brazilian pepper and other invasive shrubs in the Pineland may explain the higher mortality of these species that we encountered.

Nevertheless, periodic fires can increase resiliency and inhibit the initial establishment of exotic plants in uninvaded communities (Ross et al. 2002; Debuse and Lewis 2014). Such factors are critical for small urban preserves, where invasive plants are more prevalent in the surrounding landscape (Koptur 2006), as is the situation for the Pineland preserve. Future restoration efforts could consider manual reductions of invasive plants before and after fire prescriptions to increase fire responses to undesirable shrubs, like Brazilian pepper (Stevens and Beckage 2009), and invasive herbs that benefit from fire, like lantana (Sharma et al. 2005).

Outcomes of the first prescribed fire in the Pineland are consistent with vegetation responses to fire reintroductions in analogous fire-suppressed pine forests (Abrahamson and Abrahamson 1996), reiterating that a single fire may not be sufficient for structural restoration when fire has long been excluded. Similarly, a single introduced fire and tree trimming improved plant community composition two decades after converting an old field to scrub habitat in Florida; however, structural and compositional similarity to a natural scrub ecosystem was not fully achieved with one fire (Schmalzer and Foster 2019). Although efforts aimed at introducing fire in urban areas are minimal (Jones and Koptur 2017), our results indicate that prescribed fire in constructed ecosystems is a positive step forward in maintaining these complex ecosystems.

Maintaining fire-dependent ecosystems at the wildland-urban interface could release some pressures of habitat loss and fragmentation caused by urbanization (Diamond and Heinen 2016). Periodic fire can stimulate germination, growth, and flowering in some plants (Barrios et al. 2011; Pyke 2017), which can have a positive effect on associated animals (Dell et al. 2019). When these ecosystems are distributed across the landscape at different stages of burn recovery, diversity increases spatially (Turner 1989) and temporally. The Pineland in our study is a constructed ecosystem, but our post-burn seedling recruitment suggests that these planted native species made large contributions to the seed bank. These outcomes are promising for conserving rare and endangered ecosystems like pine rockland in urban fragments.

\section{Conclusion}

The early stages of recovery that we observed in this pine rockland forest offers insight into restoration 


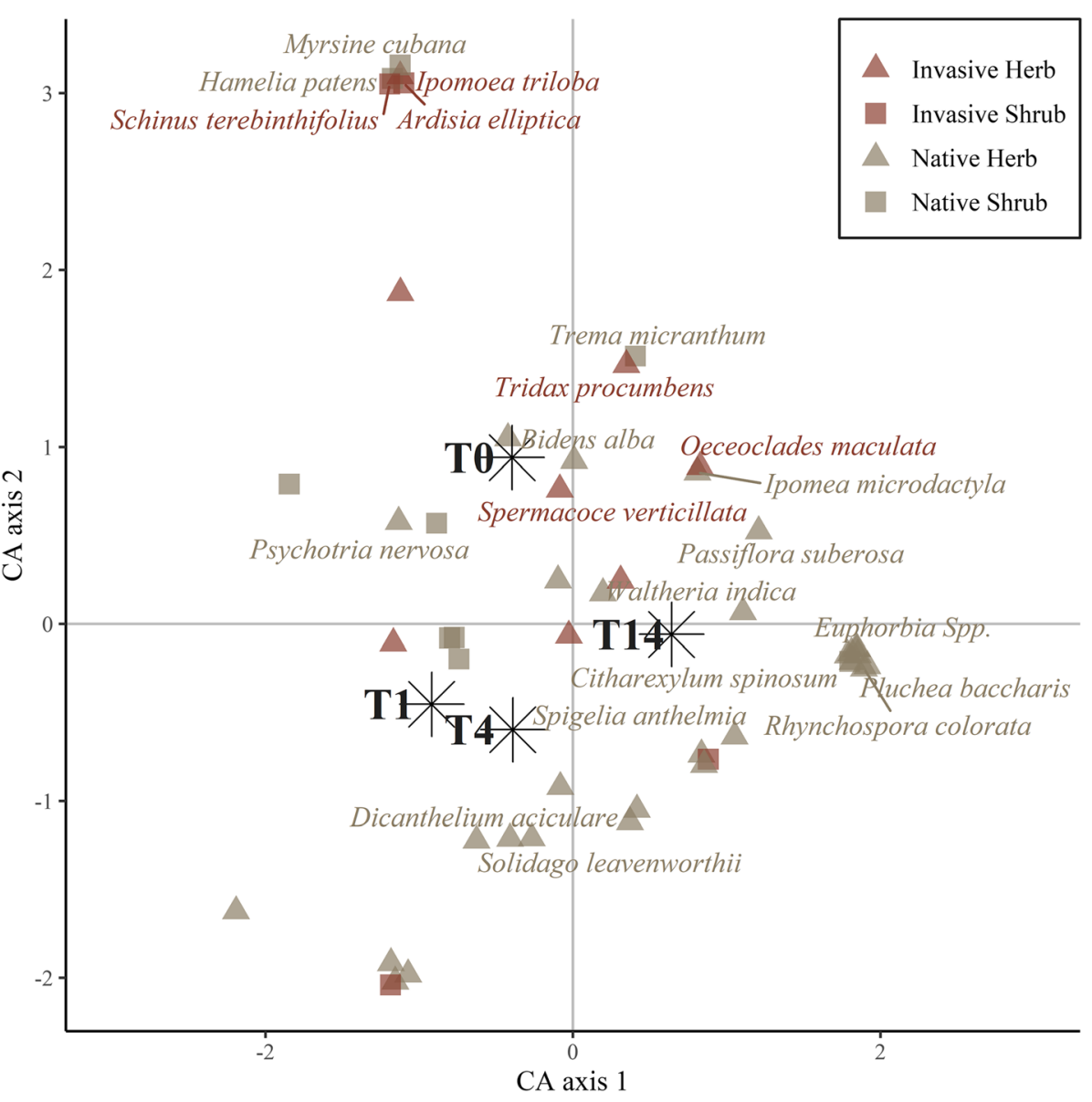

Fig. 3 Correspondence analysis (CA) of relative species frequencies following a prescribed burn within a previously unburned pine rockland fragment in South Florida, USA. Observations occurred 1 week before the prescribed burn (T0), 1 week post-burn (T1), at 4 weeks (T4), and at 14 weeks (T14). Species were scaled to preserve $X^{2}$ distances between survey times. ANOSIM results indicate that the means of ranked dissimilarities between the groups are more different than within the groups $(R=0.22, P<0.001)$. The total contribution to inertia was 0.82 , and this CA graph displays $79 \%$ of the variability. Only species contributing larger than $90 \%$ to the inertia are labeled (see Supplementary Table), and they are coded by vegetation type and regional native status in South Florida (Gann et al. 2020). Some random noise was added to species scores to visualize ( \pm 0.07 points) overlapping labels

outcomes in previously unburned fragments. Despite the high density of herbs and shrubs 14 weeks postburn, temporal diversity was high. Many novel herbs germinated post-burn, and some short-lived annuals made important contributions back to the seed bank. The burn effectively consumed much biomass and fuel loads, while cycling nutrients (Freidenreich et al. 2020), with minimal human interference. Such feasibility of prescribed burns in unburned urban patches are critical for ecosystems like the globally endangered pine rockland, in which nearly $20 \%$ of the remaining habitat occurs within urban fragments averaging less than 5 ha (USFWS 1999).

\section{Abbreviations}

ANOSIM: Analysis of similarities; CA: Correspondence analysis; Pineland: Pine rockland forest in the Florida International University Nature Preserve;

TO: Days before the prescribed burn; T1: One week after the prescribed burn;
T4: Four weeks after the prescribed burn; T14: Fourteen weeks after the prescribed burn; $X^{2}$ : Chi-squared

\section{Supplementary Information}

The online version contains supplementary material available at https://doi. org/10.1186/s42408-021-00116-1.

Additional file 1: Table S1. Plant species present in the fire-dependent pine rockland preserve at Florida International University, Miami, FL before (T0), and one (T1), four, (T4) and fourteen weeks (T14) after the first prescribed fire. Correspondence analysis axes scores represent scores for species incidences at each survey period. Vegetation type and regional native status in South Florida were provided by Institute for Regional Conservation's online database (Gann et al. 2020).

\section{Acknowledgements}

The authors would like to thank Devon Taylor for assisting in the initial data collection, Dr. Pushpa Soti for providing inspiration for the project, and Dr. Suzanne Koptur for the feedback on the final manuscript and mentoring support. We also want to thank the Sustainability Office at Florida 
International University (FIU) for administering the prescribed fire, communicating details related to the fire, and providing access after the burn. We thank the anonymous reviewers and journal editors that provided invaluable feedback on previous manuscript versions.

\section{Authors' contributions}

$\mathrm{BH}, \mathrm{AF}$, and $\mathrm{EB}$ conceived the research. $\mathrm{BH}$ collected and prepared the data, conducted the formal analysis and interpretation of the results, and wrote the original draft. $\mathrm{BH}, \mathrm{AF}$, and $\mathrm{KJ}$ reviewed the final manuscript. $\mathrm{KJ}$ provided funding. The authors read and approved the final manuscript.

\section{Funding}

This research was funded through FIU's Agroecology Program via the US Department of Agriculture-National Institute of Food and Agriculture, National Needs Fellowship (2013-38420-20499).

\section{Availability of data and materials}

The datasets analyzed during the current study are available from the corresponding author on reasonable request.

\section{Declarations}

\section{Ethics approval and consent to participate}

Not applicable

\section{Consent for publication}

Not applicable

\section{Competing interests}

The authors declare that they have no competing interests.

\section{Author details}

${ }^{1}$ Institute of Environment, Department of Biological Sciences, CASE 151, Florida International University, 11200 SW 8th St., Miami, FL 33199, USA. ${ }^{2}$ Department of Earth and Environment, CASE 159, Florida International University, 11200 SW 8th St., Miami, FL 33199, USA. ${ }^{3}$ Department of Earth and Environment, AHC5-383, Florida International University, 11200 SW 8th St., Miami, FL 33199, USA.

\section{Received: 9 April 2021 Accepted: 14 August 2021}

Published online: 05 November 2021

\section{References}

Abrahamson, W.G., and C.R. Abrahamson. 1996. Effects of fire on long-unburned Florida uplands. Journal of Vegetation Science 7 (4): 565-574. https://doi.org/1 $0.2307 / 3236306$.

Abrahamson, W.G., C.R. Abrahamson, and M.A. Keller. 2021. Lessons from four decades of monitoring vegetation and fire: maintaining diversity and resilience in Florida's uplands. Ecological Monographs 91 (2): 1-20. https://doi. org/10.1002/ecm.1444.

Alba, C., H. Skálová, K.F. Mcgregor, C. D’Antonio, and P. Py. 2015. Native and exotic plant species respond differently to wildfire and prescribed fire as revealed by meta-analysis. Journal of Vegetation Science 26 (1): 102-113. https://doi.org/10.1111/jvs.12212.

Barrios, B., G. Arellano, and S. Koptur. 2011. The effects of fire and fragmentation on occurrence and flowering of a rare perennial plant. Plant Ecology 212 (6): 1057-1067. https://doi.org/10.1007/s11258-010-9886-7.

Cannon, J.B., C.J. Peterson, J.J. O'Brien, and J.S. Brewer. 2017. A review and classification of interactions between forest disturbance from wind and fire. Forest Ecology and Management 406: 381-390 https://doi.org/10.1016/j. foreco.2017.07.035.

Chao, A., N.J. Gotelli, T.C. Hsieh, E.L. Sander, R.K. Colwell, and A.M. Ellison. 2014. Rarefaction and extrapolation with Hill numbers: a framework for sampling and estimation in species diversity studies. Ecological Monographs 84 (1): 45 67. https://doi.org/10.1890/13-0133.1.

Cohen, S., Braham, R. and Sanchez, F. 2004. Seed bank viability in disturbed longleaf pine sites. Restoration Ecology 12: 503-515. https://doi.org/10.1111/j.1 061-2971.2004.00382.x.

Colwell, R.K., X.M. Chang, and J. Chang. 2004. Interpolating, extrapolating, and comparing incidence-based species accumulation curves. Ecology. https://doi. org/10.1890/03-0557 85 (10): 2717-2727.
Cribari-Neto, F., and A. Zeileis. 2010. Beta regression in R. Journal of Statistical Software 34 (2): 1-24. https://doi.org/10.18637/jss.v034.i02.

Debuse, V.J., and T. Lewis. 2014. Long-term repeated burning reduces Lantana camara regeneration in a dry eucalypt forest. Biological Invasions 16 (12): 2697-2711. https://doi.org/10.1007/s10530-014-0697-y.

Dell, J.E., D.M. Salcido, W. Lumpkin, L.A. Richards, S.M. Pokswinski, E.L. Loudermilk, J.J. O'Brien, and L.A. Dyer. 2019. Interaction diversity maintains resiliency in a frequently disturbed ecosystem. Frontiers in Ecology and Evolution 7: 1-9 https://doi.org/10.3389/fevo.2019.00145.

Diamond, J.M., and J.T. Heinen. 2016. Conserving rare plants in locally-protected urban forest fragments: a case study from Miami-Dade County, Florida. Urban Forestry \& Urban Greening 20: 1-11 https://doi.org/10.1016/j.ufug.2016.07.008.

Dunn, R.R., M.C. Gavin, M.C. Sanchez, and J.N. Solomon. 2006. The pigeon paradox: dependence of global conservation on urban nature. Conservation Biology 20 (6): 1814-1816. https://doi.org/10.1111/j.1523-1739.2006.00533.x.

Elmqvist, T., H. Setala, S.N. Handel, S. Van Der Ploeg, J. Aronson, J.N. Blignaut, E. Gomez-Baggethun, D.J. Nowak, J. Kronenberg, and R. De Groot. 2015. Benefits of restoring ecosystem services in urban areas. Current Opinion in Environmental Sustainability 14: 101-108 https://doi.org/10.1016/j.cosust.2015. 05.001.

Folke, C., S.R. Carpenter, B. Walker, M. Scheffer, T. Elmqvist, L. Gunderson, and C.S. Holling. 2004. Regime shifts, resilience, and biodiversity in ecosystem management. Annual Review of Ecology, Evolution, and Systematics 35 (1): 557-581. https://doi.org/10.1146/annurev.ecolsys.35.021103.105711.

Freidenreich, A., B.M. Harris, S. Dattamudi, E. Betancourt, M.S. Reis, and K. Jayachandran. 2020. Effects of prescribed fire on soil properties in a pine rockland ecosystem. Agricultural \& Environmental Letters, https://doi.org/10.1 002/ael2.20026 5 (1).

Gann, G.D., C.G. Stocking, and Collaborators. 2020. Floristic Inventory of South Florida Database Online. The Institute for Regional Conservation. Delray Beach, Florida.

Hsieh, T.C., K.H. Ma, and A. Chao. 2016. iNEXT : an R package for rarefaction and extrapolation of species diversity (Hill numbers). Methods in Ecology and Evolution 7 (12): 1451-1456. https://doi.org/10.1111/2041-210X.12613.

Jennings, S. 1999. Assessing forest canopies and understorey illumination: canopy closure, canopy cover and other measures. Forestry. https://doi.org/10.1093/ forestry/72.1.59 72 (1): 59-74.

Johnstone, J.F., C.D. Allen, J.F. Franklin, L.E. Frelich, B.J. Harvey, P.E. Higuera, M.C. Mack, R.K. Meentemeyer, M.R. Metz, G.L.W. Perry, T. Schoennagel, and M.G. Turner. 2016. Changing disturbance regimes, ecological memory, and forest resilience. Frontiers in Ecology and the Environment 14 (7): 369-378. https:// doi.org/10.1002/fee.1311.

Jones, I.M., and S. Koptur. 2017. Dead land walking: the value of continued conservation efforts in South Florida's imperiled pine rocklands. Biodiversity and Conservation 26 (14): 3241-3253. https://doi.org/10.1007/s10531-01 7-1433-6.

Kobziar, L.N., D. Godwin, L. Taylor, and A.C. Watts. 2015. Perspectives on trends, effectiveness, and impediments to prescribed burning in the southern U.S. Forests 6 (12): 561-580. https://doi.org/10.3390/f6030561.

Koptur, S. 2006. The conservation of specialized and generalized pollination systems in subtropical ecosystems: a case study. In Plant-pollinator interactions: from specialization to generalization, ed. N. Waser and J. Ollerton, 341-361.

Legendre, P., and L. Legendre. 2012. Numerical ecology. 3rd ed. Elsevier.

Liu, H., E.S. Menges, and P.F. Quintana-Ascencio. 2005. Population viability analysis of Chamaecrista keyensis: effects of fires season and frequency. Ecological Applications 15 (1): 210-221. https://doi.org/10.1890/03-5382.

Lundholm, J.T. 2015. The ecology and evolution of constructed ecosystems as green infrastructure. Frontiers in Ecology and Evolution 3: 1-7 https://doi.org/1 0.3389/fevo.2015.00106

Mitchell, R.J., J.K. Hiers, and J.J. O'Brien. 2009. Ecological forestry in the Southeast: understanding the ecology of fuels. Journal of Forestry, December: 391-397.

O'Brien, J. J. 1998. The distribution and habitat preferences of rare Galactia species (Fabaceae) and Chamaesyce deltoidea subspecies (Euphorbiaceae) native to southern Florida pine rockland. Natural Areas Journal 18 (3), 208222.

Oksanen, L. 2001. Logic of experiments in ecology: is pseudoreplication a pseudoissue? Oikos 94 (1): 27-38. https://doi.org/10.1034/j.1600-0706.2 001.11311.x.

Ormeño, E., B. Cespedes, A. Velasco-garcıa, J.M. Moreno, C. Fernandez, and V. Baldy. 2009. The relationship between terpenes and flammability of leaf litter. 
Forest Ecology and Management 257: 471-482 https://doi.org/10.1016/j. foreco.2008.09.019.

Possley, J.E., J.M. Maschinski, J. Maguire, and C. Guerra. 2014. Vegetation monitoring to guide management decisions in Miami's Urban Pine Rockland Preserves. Natural Areas Journal 34 (2): 154-165. https://doi.org/10.3375/043. 034.0205.

Pyke, G.H. 2017. Fire-stimulated flowering: a review and look to the future. Critical Reviews in Plant Sciences 36 (3): 179-189. https://doi.org/10.1080/07352689.2 017.1364209 .

Ross, K.A., B.J. Fox, and M.D. Fox. 2002. Changes to plant species richness in forest fragments: fragment age, disturbance and fire history may be as important as area. Journal of Biogeography. https://doi.org/10.1046/j.1365-2699.2002. 00722.x 29 (5-6): 749-765.

Ross, M.S., J.J. O'Brien, R.G. Ford, K. Zhang, and A. Morkill. 2009. Disturbance and the rising tide: the challenge of biodiversity management on low-island ecosystems. Frontiers in Ecology and the Environment 7 (9): 471-478. https:// doi.org/10.1890/070221.

Ryan, K.C., E.E. Knapp, and J.M. Varner. 2013. Prescribed fire in North American forests and woodlands: history, current practice, and challenges. Frontiers in Ecology and the Environment 11: e15-e24.

Schmalzer, P.A., and T.E. Foster. 2019. Restoration of Florida scrub vegetation in an old field through 23 years after planting. Restoration Ecology 27 (2): 320 332. https://doi.org/10.1111/rec.12864.

Sharma, G.R., A.S. Raghubanshi, and J.S. Singh. 2005. Lantana invasion: an overview. Weed Biology and Management 5 (4): 157-165. https://doi.org/1 0.1111/j.1445-6664.2005.00178.x

Snyder, J.R., A. Herndon, and W.B. Robertson Jr. 1990. South Florida rockland. In Ecosystems of Florida, ed. R. Myers and J. Ewel, 230-277. University of Central Florida Press http://pubs.er.usgs.gov/publication/85776.

Snyder, J.R., M.S. Ross, S. Koptur, and J.P. Sah. 2005. Developing ecological criteria for prescribed fire in South Florida pine rockland ecosystems. Open-File Report 2005: 109 http://pubs.er.usgs.gov/publication/ofr20061062.

Stevens, J.T., and B. Beckage. 2009. Fire feedbacks facilitate invasion of pine savannas by Brazilian pepper (Schinus terebinthifolius). The New Phytologist 184 (2): 365-375 https://doi.org/10.1111/j.1469-8137.2009.02965.x.

Templ, M., K. Hron, and P. Filzmoser. 2011. robCompositions: an R-package for robust statistical analysis of compositional data. In Compositional Data Analysis, 341-355 https://doi.org/10.1002/9781119976462.ch25.

Turner, M.G. 1989. Landscape ecology : the effect of pattern on process. Ecology 20: $171-197$.

U.S. Fish and Wildlife Service. 1999. South Florida multi-species recovery plan, 2172. Atlanta, Georgia.

van den Boogaart, K.G., and R. Tolosana-Delgado. 2013. Analyzing compositional data with R. Vol. 5. Berlin Heidelberg. https://doi.org/10.1007/978-3-642-3 6809-7: Springer-Verlag.

van Wilgen, B.W., G.G. Forsyth, and P. Prins. 2012. The management of fireadapted ecosystems in an urban setting: the case of table mountain National Park, South Africa. Ecology and Society 17 (1) https://doi.org/10.5751/ES-0452 6-170108.

\section{Publisher's Note}

Springer Nature remains neutral with regard to jurisdictional claims in published maps and institutional affiliations.

\section{Submit your manuscript to a SpringerOpen ${ }^{\circ}$ journal and benefit from:}

- Convenient online submission

- Rigorous peer review

- Open access: articles freely available online

- High visibility within the field

- Retaining the copyright to your article

Submit your next manuscript at $\boldsymbol{\nabla}$ springeropen.com 